\title{
Monitoring Land Cover Change: Towards Sustainability
}

\author{
Ioannis Manakos ${ }^{1, *(\mathbb{D}}$, Garik Gutman ${ }^{2}$ and Chariton Kalaitzidis ${ }^{3}[$ \\ 1 Centre for Research and Technology Hellas, Information Technologies Institute, 6th km Harilaou-Thermi, \\ 57001 Thessaloniki, Greece \\ 2 NASA Headquarters, Washington, DC 20546, USA; ggutman@nasa.gov \\ 3 Department of Geoinformation in Environmental Management, Mediterranean Agronomic Institute of \\ Chania, 73100 Chania, Greece; chariton@maich.gr \\ * Correspondence: imanakos@iti.gr; Tel.: +30-2311-257-760
}

check for updates

Citation: Manakos, I.; Gutman, G.; Kalaitzidis, C. Monitoring Land Cover Change: Towards Sustainability. Land 2021, 10, 1356. https://doi.org/10.3390/ land10121356

Received: 25 November 2021 Accepted: 25 November 2021 Published: 9 December 2021

Publisher's Note: MDPI stays neutral with regard to jurisdictional claims in published maps and institutional affiliations.

Copyright: (c) 2021 by the authors. Licensee MDPI, Basel, Switzerland. This article is an open access article distributed under the terms and conditions of the Creative Commons Attribution (CC BY) license (https:// creativecommons.org/licenses/by/ $4.0 /)$.
In 2015, the United Nations member states adopted the 2030 Agenda, within which the 17 Sustainable Development Goals (SDGs) were established, with many of these goals calling for further research into sustainability. In particular, systematic issues with data, monitoring and accountability were underlined, especially as these issues concerned the provision of support for developing countries. Because Earth observation methods can provide the means for timely and accurate monitoring of the Earth's surface and atmosphere, progress in research and technology can help improve the amount and quality of data recorded for supporting the achievement of the SDGs.

The Paris Agreement, adopted in December 2015 within the framework of the UN's Framework Convention on Climate Change (UNFCCC), aimed to limit the increase in global temperature to less than $1.5{ }^{\circ} \mathrm{C}$. To help accomplish this goal, the framework for Reducing Emissions from Deforestation and Forest Degradation (REDD+) was established with the aim of assisting national governments in reducing human pressure on forests-one of the key causes of the increase in greenhouse gas emissions. REDD+ activities undoubtedly present opportunities for synergies between those who aim to achieve a range of SDGs $[1,2]$.

This Special Issue is linked with the 38th Annual Symposium of the European Association of Remote Sensing Laboratories (EARSeL) and the concurrent 3rd Joint EARSeL Land Use Land Cover and NASA Land-Cover/Land-Use Change Workshop, which took place on 9-12 July 2018. It contains 13 peer-reviewed papers, most of which were originally presented at the symposium and workshop. Relevant subsequent external submissions are also included here. The authors of these papers are from various countries, including Austria, Belgium, Brazil, China, Costa Rica, Germany, Kenya, Papua New Guinea, Poland, Switzerland and the USA. Research areas range from the entire globe to large regions (Europe, East Africa) to specific countries (Ghana, Malawi, Nigeria).

The conversion of forest cover to agricultural land or urban areas has significant climate change impacts. Forest removal releases carbon dioxide into the atmosphere, adding to the global warming process and resulting in changes to the local and regional climate. Hewson et al. [3] have developed a global dataset with a $1 \mathrm{~km}$ resolution that helps to assess the risks of tree cover loss between 2000 and 2014, and have made projections for up to 2029. This work helps identify the areas with a higher threat of deforestation, and provides a useful tool for climate change mitigation, biodiversity conservation and achieving the SDGs. In a study by Hirschmugl et al. [4], Sentinel-1 and -2 data time series are combined to focus on forest cover monitoring in Malawi as part of the aims of the UNFCCC (United Nations Framework Convention on Climate Change) and REDD+. Forest cover has been under significant pressure from both agricultural land expansion and urban sprawl in many developing areas of the world, studied both at a local scale [5-7], as well as at a regional scale [8]. Population growth in developing countries results in 
increasing demand for urban space and agricultural land for food production [5]. Longterm time-series data are used in both the developing and more developed countries as a tool for analyzing land use and land cover change [9-11], often combined with other data to increase the monitoring accuracy $[12,13]$. Spatial analysis is also used to help identify other factors that contribute to forest cover change, such as cultural factors [14], or to monitor the impact of other implemented measures that are geared towards the increase of vegetative cover [15].

As technology developments bring forward more advanced sensors and platforms for monitoring land use and land cover change, with the process of data acquisition and processing becoming more affordable, Earth observation data and information will facilitate even further the planning efforts by authorities, both in developed and developing countries, bringing us closer to achieving the SDGs globally.

Author Contributions: All authors contributed equally. All authors have read and agreed to the published version of the manuscript.

Funding: This research received no external funding.

Informed Consent Statement: Not applicable.

Acknowledgments: We would like to acknowledge the European Association of Remote Sensing Laboratories and the NASA Land-Cover/Land-Use Change Program for providing the discussion and networking platform for many of the articles included in this special issue, as well as the scientific and organizing committees involved in these two events.

Conflicts of Interest: The authors declare no conflict of interest.

\section{References}

1. Bastos Lima, M.G.; Kissinger, G.; Visseren-Hamakers, I.J.; Braña-Varela, J.; Gupta, A. The Sustainable Development Goals and REDD+: Assessing institutional interactions and the pursuit of synergies. Int. Environ. Agreem. Politics Law Econ. 2017, 17, 589-606. [CrossRef]

2. Bernard, F.; Rosenstock, T.; Neely, C. REDD+ and the 2030 Sustainable Development Goals: Linkages and Lessons Learnt in the Democratic Republic of Congo; Policy Brief No. 41; World Agroforestry Centre: Nairobi, Kenya, 2018.

3. Hewson, J.; Crema, S.C.; González-Roglich, M.; Tabor, K.; Harvey, C.A. New 1 km Resolution Datasets of Global and Regional Risks of Tree Cover Loss. Land 2019, 8, 14. [CrossRef]

4. Hirschmugl, M.; Sobe, C.; Deutscher, J.; Schardt, M. Combined Use of Optical and Synthetic Aperture Radar Data for REDD+ Applications in Malawi. Land 2018, 7, 116. [CrossRef]

5. Essien, E.; Cyrus, S. Detection of Urban Development in Uyo (Nigeria) Using Remote Sensing. Land 2019, 8, 102. [CrossRef]

6. Doaemo, W.; Mohan, M.; Adrah, E.; Srinivasan, S.; Dalla Corte, A.P. Exploring Forest Change Spatial Patterns in Papua New Guinea: A Pilot Study in the Bumbu River Basin. Land 2020, 9, 282. [CrossRef]

7. Frimpong, B.F.; Molkenthin, F. Tracking Urban Expansion Using Random Forests for the Classification of Landsat Imagery (1986-2015) and Predicting Urban/Built-Up Areas for 2025: A Study of the Kumasi Metropolis, Ghana. Land 2021, 10, 44. [CrossRef]

8. Bullock, E.L.; Healey, S.P.; Yang, Z.; Oduor, P.; Gorelick, N.; Omondi, S.; Ouko, E.; Cohen, W.B. Three Decades of Land Cover Change in East Africa. Land 2021, 10, 150. [CrossRef]

9. Nguyen, L.H.; Joshi, D.R.; Henebry, G.M. Improved Change Detection with Trajectory-Based Approach: Application to Quantify Cropland Expansion in South Dakota. Land 2019, 8, 57. [CrossRef]

10. Arnold, C.; Wilson, E.; Hurd, J.; Civco, D. 30 Years of Land Cover Change in Connecticut, USA: A Case Study of Long-Term Research, Dissemination of Results, and Their Use in Land Use Planning and Natural Resource Conservation. Land $2020,9,255$. [CrossRef]

11. Close, O.; Petit, S.; Beaumont, B.; Hallot, E. Evaluating the Potentiality of Sentinel-2 for Change Detection Analysis Associated to LULUCF in Wallonia, Belgium. Land 2021, 10, 55. [CrossRef]

12. Close, O.; Benjamin, B.; Petit, S.; Fripiat, X.; Hallot, E. Use of Sentinel-2 and LUCAS Database for the Inventory of Land Use, Land Use Change, and Forestry in Wallonia, Belgium. Land 2018, 7, 154. [CrossRef]

13. Gibas, P.; Majorek, A. Analysis of Land-Use Change between 2012-2018 in Europe in Terms of Sustainable Development. Land 2020, 9, 46. [CrossRef]

14. Cui, N.; Zou, H.; Zhang, M.; Guo, L. The Effects of Terrain Factors and Cultural Landscapes on Plateau Forest Distribution in Yushu Tibetan Autonomous Prefecture, China. Land 2021, 10, 345. [CrossRef]

15. Zhang, X.; Deng, Y.; Hou, M.; Yao, S. Response of Land Use Change to the Grain for Green Program and Its Driving Forces in the Loess Hilly-Gully Region. Land 2021, 10, 194. [CrossRef] 